\title{
The current status of the rare Scottish endemic Hieracium drummondii Drummond's hawkweed (Asteraceae)
}

\author{
Timothy C. G. Rich \\ Cardiff, U.K.
}

Corresponding author: Timothy C. G. Rich: tim rich@sky.com

This pdf constitutes the Version of Record published on $30^{\text {th }}$ June 2020

\begin{abstract}
The records of Hieracium drummondii Pugsley, Drummond's hawkweed, (Asteraceae) are reviewed. It has been recorded from eight general localities and it not accepted in four others. Seven of the eight localities have been visited but only one population of 20-25 plants was found at Crinan. It is IUCN Threat Category 'Critically Endangered' and is on the verge of extinction.
\end{abstract}

Keywords: Critically Endangered; endemic; IUCN Threat Category; Scotland.

\section{Introduction}

Hieracium drummondii Pugsley, Drummond's hawkweed, is a rare Scottish endemic. It was first described by H. W. Pugsley from material collected by Tom Drummond at Linn Mill, Clackmannanshire in 1876 (Pugsley, 1948). Pugsley listed it from Linnell [Linn Mill] and Aberdona in v.c.87 West Perth and from Careston in v.c.90 Forfar. Sell \& West (1968) mapped it in six hectads including additional sites in v.c.84 West Lothian, 98 Argyll and 101 Kintyre. McCosh \& Rich $(2011,2018)$ mapped it in 11 hectads including additional records from v.c.73 Kirkcudbrightshire and 94 Morayshire.

As part of a project to collect seeds of rare endemic hawkweeds for the Millennium Seed Bank, Royal Botanic Garden Kew, I attempted to collected seed of H. drummondii in 2016 and 2017 without success (Rich, 2018). This prompted a review of the records and further field survey in 2019, the results of which are presented below.

Hieracium drummondii is distinguished from the other British and Irish members of Hieracium section Foliosa (Fr.) Arv.-Touv. by the combination of dark styles, predominantly glandular-hairy, narrow $0.9-1.2 \mathrm{~mm}$ wide bracts and usually sparse to dense stellate hairs on both sides of the upper leaves.

\section{Methods}

Data were compiled primarily from herbarium material in BM, DUE, CGE, E, MANCH, NMW and RNG, many determined by P. D. Sell, C. West and D. McCosh, though some were revised following closer examination. In addition, the Hieracium database of D. McCosh and the BSBI Distribution Database were consulted, and relevant local Floras were checked. 


\section{Results}

Carsphairn (v.c.73 Kirkcudbrightshire)

Hieracium drummondii was found on 31 August 1994 by O. M. Stewart at NX556940 on rough grassland north of Carsphairn (E; a second specimen from this site with yellow styles collected the day before on 30 August 1994 was redetermined as $H$. latobrigorum (Zahn) Roffey by TR in 2019, E). This grid reference and area was visited on 19 July 2016 without success. There are patches of rank, rough scrubby grassland west of the A713, the verges have tall, rank vegetation mown to $1 \mathrm{~m}$ wide and the adjacent old road/layby has shaded verges with one patch of $H$. triviale $(H$. vulgatum auct.). The Water of Deugh riverbanks are either grazed or partially shaded with dense Luzula sy/vatica and on the east side had H. lissolepium Roffey, H. triviale (Norrl.) Norrl. and H. sparsifolium Lindeb.

\section{Linlithgow (v.C.84 West Lothian)}

Hieracium drummondii was collected from banks of the Avon, Linlithgow on September 1838 by W. H. Campbell (CGE, E). On 18 August 2019, readily accessible banks of the River Avon were searched as far south as Muiravonside Country Park without success, but large lengths of riverbank with difficult access remain to be investigated.

\section{Aberdona (v.c.87 West Perth)}

Hieracium drummondii was first collected at Aberdona on 13 August 1874 by J. R. \& T. Drummond (BM), and then on 12 August 1875 by T. Drummond (BM), then again 'on the road between Forest Mill and Dollar, $250 \mathrm{ft}$ ' [76 m] on 14 August 1876 (BM, CGE) and on 4 September 1876 (BM, MANCH). J. R. \& T. Drummond were at the time working on a proposed flora of Clackmannanshire. Some of these specimens with different handwriting were labelled as collected by Dr Boswell []. T. I. B. Syme] but it is more likely all were collected by T. Drummond whose name is consistently on the labels in the herbarium of Dr Boswell.

There were no further records until J. E. Raven refound it at Aberdona on 2 August 1952 (RNG, herb. McCosh). J. W Carder and C. West collected it on a 'low, grassy' roadside bank at Aberdona in August 1953 (CGE). P. D. Sell, N. D. Simpson and C. West collected it from a 'high roadside bank' at Forest Mill, NS954943 [NB some databases have an erroneous version of this grid reference as NS952939] on 30 July 1959 (BM, CGE). In total these records may represent at least three sites.

The Dollar to Forest Mill verges was searched on foot and by driving slowly on 7 August 2016 and 31 July 2017 without success, though there was plenty of suitable habitat. D. J. \& T. McCosh similarly failed to find any in the Aberdona area in August 2017 (pers. comm. 2017).

\section{Linn Mill (v.c.87 West Perth)}

Hieracium drummondii was first collected at Linn Mill on July 1876 by J. T. I. B. Syme (though see comment about the collector above for Aberdona; BM, CGE) and then on 17 August 1876 by T. Drummond (BM (holotype), CGE). Linn Mill was visited on 7 August 2016 and verges, the old railway line and stream-sides of the Black Devon around the old ruined Linn Mill were searched without success (one plant of H. strictiforme (Zahn) Roffey occurred at NS925930). 
Careston (v.c.90 Forfar)

Hieracium drummondii was found on a roadside bank between Careston Station and Hilton of Fern on 23 July 1933 by R. H. Corstorphine (BM, DUE; Ingram \& Noltie, 1981). The area is now predominantly improved pasture and arable with Arrhenatherum-dominated verges and looks generally unsuitable. D. J. McCosh looked at the Careston area a few years ago without success (pers. comm. 2017).

\section{Spey Mouth (v.c.94 Banffshire)}

A specimen determined by P. D. Sell \& C. West as H. drummondii was collected on 28 August 1968 by M. McCallum Webster on rough ground at the east bank of the River Spey at Spey Mouth (CGE); independent re-examination of the material by D. McCosh (undated) and by TR in 2019 showed it had many long simple hairs in the inflorescence and was $H$. strictiforme. A second specimen collected and determined as $H$. drummondii by M. McCallum Webster from a path by the River Spey at Tugnet in NJ3465 on 25 July 1984 is also H. strictiforme (BM). These records are therefore not accepted.

Boat of Garten (v.c.95 Moray)

McCallum Webster (1978) reported H. drummondii on the left [west] bank of the River Spey upstream of Boat of Garten [NH9418] in 1973 and cited a specimen in E, apparently determined by P. D. Sell \& C. West; this specimen has not been traced. The locality was searched by I. P. Green in 2016 and by TR in 2019; H. strictiforme and $H$. subumbellatiforme (Zahn) Roffey were both scattered along this section of river, the former also recorded by McCallum Webster (1978). In the absence of the voucher and in light of redetermination of her v.c.94 records above, this record is not accepted without a voucher either.

KiImartin - Ford road junction (v.c.98 Argyll)

Hieracium drummondii was collected at the Ford-Kilmartin road junction (some databases cite it incorrectly as a cross roads), NM842011 by A. G. Kenneth on 27 August 1961 (CGE). The grid reference refers to a patch of woodland NW of the junction with heavily shaded stream-sides and a salmon farm. The stream-sides, road junction, verges and adjacent woodland edges were searched on 8 July and 29 Aug 2017 without success.

Crinan (v.c.101 Kintyre)

Hieracium drummondii has been recorded in about four sites around Crinan (Cunningham \& Kenneth, 1979). A. G. Kenneth first recorded it in good quantity on the roadside up the steep hill from the Crinan Canal north basin at NR787942 on 20 August 1960 (CGE). The following year on 11 August 1961 he recorded it on the roadside by the Crinan Canal about a kilometre SSE at NR790931 (CGE). J. N. Mills collected it from cliffs above the road, NR787944[5] at Crinan Hotel (MANCH). J. N. Mills and A. G. Kenneth collected it on 8 August 1968 from walls and rocks at NR788943 (this probably equates to the first site) and also nearby from grassy banks above road, NR786941 (MANCH). This latter site is probably where A. G. Kenneth also collected it 'near road fork' on 28 August 1969 (CGE). 
These four sites and adjacent areas were searched 8 July and 29 Aug 2017 without success, the cliffs above the hotel are now covered with dense rhododendron and the roadsides are managed. Finally on 13 August 2019 a small population of 20-25 H. drummondii plants with a few H. strictiforme plants was found on the sea wall below the Crinan Hotel at NR78889446 (herb. TR, herb. McCosh) (Fig.1).

\section{Barr Glen (v.c.101 Kintyre)}

Cunningham \& Kenneth (1979) listed H. drummondii for 'Barr Glen: near Muasdale' (NR63); the record is also listed as 1953 Atlas of the British flora 10-km square mastercard. No voucher has been traced (assuming the 1953 Muasdale shore record below does not relate to this site) and this site has not been revisited.

\section{Muasdale (v.c.101 Kintyre)}

There are two records (Cunningham \& Kenneth, 1979): Muasdale shore, rock face, 8 August 1953, M. H. Cunningham (BM) and near Muasdale, near NR680405, 1 September 1963, A. G. Kenneth (CGE).

The Muasdale area was searched on 13 August 2019 without success. The large roadside rocks on the shore at Kenneth's grid reference look potentially suitable habitat but some may have been lost to road straightening and only $H$. triviale was present. Roadsides for $c .1 \mathrm{~km}$ north and south of Muasdale and the Clachaig Water in Muasdale were unsuitable.

Subsequent re-examination of the original vouchers in Autumn 2019 showed both specimens had broad bracts (up to $c .2 \mathrm{~mm}$ wide) with lots of simple hairs and whilst the upper leaves had stellate hairs on both sides the specimens are better included in $\mathrm{H}$. strictiforme. These records are not accepted.

\section{Eigg (v.c. 104 North Ebudes)}

Hieracium drummondii was collected from Laig Gorge [incorrectly transcribed as Larig Gorge], Eigg on 9 August 1971 by C. W. Murray (CGE). This locality has not yet been revisited.

\section{Discussion}

A review of the records for $H$. drummondii shows of the 12 general localities from which it has been recorded, four are currently rejected or not accepted without evidence. A difference of opinion as to the weight of various characters in defining $H$. drummondii is the cause of rejection of some records. Pugsley (1948) characterised $H$. drummondii as having vigorous, leafy stems with relatively small flower heads with narrow glandular rather than pilose bracts. Sell \& Murrell's (2006) key and description emphasises $H$. drummondii having leaves stellately-hairy on both sides (more specifically the upper leaves in their description) as well as numerous glandular hairs with few simple eglandular hairs on the bracts. When reviewing good material of the closely related $H$. strictiforme I have occasionally found plants with upper leaves stellately-hairy on both sides, and in general the occurrence of stellate hairs on the leaves is variable across most of section Foliosa. Hence here I downweight stellately-hairy leaves and instead focused on Pugsley's original concept of plants with notably glandular bracts. 


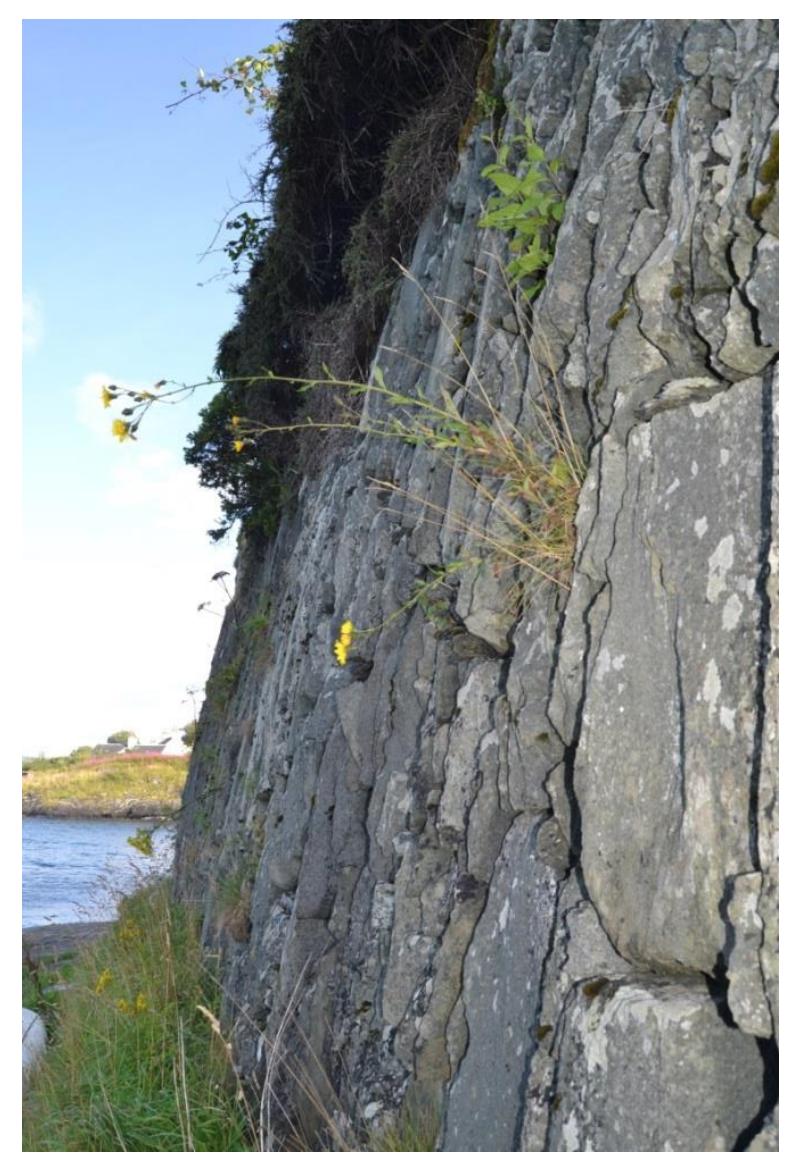

Figure 1. Hieracium drummondii below the Crinan Hotel (v.c.101).

However, even within Pugsley's species concept there is variation. The original material from central southern Scotland (e.g. Linn Mill and Aberdona) forms a uniform set of robust plants with glandular-hairy heads and leaves stellately-hairy on both sides, but material from elsewhere is more varied. The material from Eigg is relatively slender and looks different to the other material but fits Pugsley's concept, but a similar slender specimen from SE of Carloway (v.c.110) has predominantly glandular heads (cf. $H$. drummondii) but is otherwise $H$. strictiforme (E).

This rare Scottish endemic is on the verge of extinction. Of the eight confirmed localities in seven hectads, seven localities have been searched and it has only been found in one small population at Crinan, and is thus confirmed as IUCN (2001) Threat Category 'Critically Endangered' (McCosh \& Rich, 2018). It could persist in some former localities but has not been refound (it took three attempts to refind it at Crinan) and could be in other sites as yet undiscovered. It is hard to say why it has declined, there being much potentially suitable habitat still present in most localities.

\section{Acknowledgements}

I thank the Keepers of BM, DUE, CGE, E, MANCH, NMW and RNG for access to the collections, Dave Batty, Lauren Gardner, Ian Green, John Hunnex, Matthew Jarron, Lesley Scott and Sally Whyman for their help and David McCosh for constant help and advice. 
This work was partly funded by the Esmée Fairbairn Foundation as part of the UK Flora Project at the Millennium Seed Bank and partly funded with a BSBI Science \& Research Grant.

\section{References}

Cunningham, M.N. \& Kenneth, A.G. 1979. The flora of Kintyre. Wakefield: EP Publishing Ltd.

Ingram, R. \& Noltie, H.J. 1981. The Flora of Angus (Forfar v.c.90). Dundee: Dundee Museums \& Art Galleries.

IUCN 2001. IUCN Red list categories and criteria. Version 3.1. Gland: International Union for Conservation of Nature.

McCosh, D.J. \& Rich, T.C.G. 2011. Atlas of British and Irish Hawkweeds (Pilosella Hill and Hieracium L.). London: Botanical Society of the British Isles.

McCosh, D.J. \& Rich, T.C.G. 2018. Atlas of British and Irish Hawkweeds (Pilosella Hill and Hieracium L.). 2nd ed. Harpenden: Botanical Society of Britain and Ireland.

McCallum Webster, M. 1978. Flora of Moray, Nairn \& East Inverness. Aberdeen: Aberdeen University Press.

Pugsley, H.W. 1948. A Prodromus of the British Hieracia. Journal of the Linnean Society of London (Botany), 54: 1-356.

Rich, T.C.G. 2018. Millennium Seed Bank UK Flora Project. Seed collecting report for 2016-2017. 18 January 2018. Cardiff: Unpublished report to Royal Botanic Gardens, Kew.

Sell, P.D. \& West, C. 1968. Hieracium L. In: Perring, F. H., ed., Critical Supplement to the Atlas of the British flora. London: Botanical Society of the British Isles.

Copyright retained by author(s). Published by BSBI under the terms of the Creative Commons Attribution 4.0 International Public License.

ISSN: 2632-4970

https://doi.org/10.33928/bib.2020.02.127 